Cinémas

Revue d'études cinématographiques

Journal of Film Studies

\title{
Cronenberg, Flyness, and the Other-self
}

\section{William Beard}

Volume 4, numéro 2, hiver 1994

URI : https://id.erudit.org/iderudit/1001028ar

DOI : https://doi.org/10.7202/1001028ar

Aller au sommaire du numéro

\section{Éditeur(s)}

Cinémas

ISSN

1181-6945 (imprimé)

1705-6500 (numérique)

Découvrir la revue

Citer cet article

Beard, W. (1994). Cronenberg, Flyness, and the Other-self. Cinémas, 4(2),

153-173. https://doi.org/10.7202/1001028ar

\section{Résumé de l'article}

Le travail récent de David Cronenberg a montré un prolongement des thèmes et motifs retrouvés dans ses oeuvres exploratoires et formelles des années 70 et du début des années 80 . Les rapports entre l'esprit et le corps, la rationalité et la chair, le contrôle et la perte d'identité continuent d'être la dichotomie dominante de son univers filmique. Mais les oppositions thématiques relativement simples et non étudiées de répression et d'explosion avec leurs émotions correspondantes du détachement ironique et du dégoût, présentes dans un film comme Shivers (1975), ont donné place dans les années 80 à une exploration beaucoup plus complexe et sensitive de la compréhension des choses de Cronenberg. L'auteur entreprend, dans cet article, une étude attentive du film The Fly (La Mouche, 1986), en tant qu'illustration partielle de ce procédé de continuité et de raffinement. 


\title{
Cronenberg, Flyness, and the Other-self
}

\section{William Beard}

\section{RÉSUMÉ}

Le travail récent de David Cronenberg a montré un prolongement des thèmes et motifs retrouvés dans ses œuvres exploratoires et formelles des années 70 et du début des années 80 . Les rapports entre l'esprit et le corps, la rationalité et la chair, le contrôle et la perte d'identité continuent d'être la dichotomie dominante de son univers filmique. Mais les oppositions thématiques relativement simples et non étudiées de répression et d'explosion avec leurs émotions correspondantes du détachement ironique et du dégoût, présentes dans un film comme Shivers (1975), ont donné place dans les années 80 à une exploration beaucoup plus complexe et sensitive de la compréhension des choses de Cronenberg. L'auteur entreprend, dans cet article, une étude attentive du film The Fly (La Mouche, 1986), en tant qu'illustration partielle de ce procédé de continuité et de raffinement.

\begin{abstract}
David Cronenberg's recent work has shown a continuation of the same themes and motifs found in his exploratory and formative works of the 70 s and early $80 \mathrm{~s}$. The relationship of mind and body, of rationality and flesh, of control and loss of identity, continues to be the dominating dichotomy of his cinematic world. But the relatively simple thematic oppositions of repression and explosion, and their relatively unexamined emotional underpinnings of ironic detachment and regurgitative disgust, of an early film like Shivers (1975) have given way in the 1980 s to a much more complex
\end{abstract}


and sensitive exploration of the causes and implications of Cronenberg's understanding of things. The author proposes, in this essay, to undertake a close examination of Cronenberg's 1986 film The Fly as a partial illustration of this process of continuation and refinement.

David Cronenberg's recent work has shown a continuation of the same themes and motifs found in his exploratory and formative works of the $70 \mathrm{~s}$ and early $80 \mathrm{~s}$. The relationship of mind and body, of rationality and flesh, of control and loss of identity, continues to be the dominating dichotomy of his cinematic world. ${ }^{1}$ But the relatively simple thematic oppositions of repression and explosion, and their relatively unexamined emotional underpinnings of ironic detachment and regurgitative disgust, of an early film like Shivers (1975) have given way in the 1980s to a much more complex and sensitive exploration of the causes and implications of Cronenberg's understanding of things. I propose in this essay to undertake a close examination of Cronenberg's 1986 film The Fly as a partial illustration of this process of continuation and refinement. ${ }^{2}$

Cronenberg's world has always been characterized by philosophical pessimism, intellectual schizophrenia, and horror and sadness in the emotional sphere. The existential landscape of his films has been one of repetitively, unreconcilably clashing opposites, of a failure to mediate between the heterogenous aspects of human nature, of the tragic waste and destruction of human life that results from this inability to comprehend and embrace contrary qualities. But in the past decade the locus of chaos and loss has undergone a shift: from Social, Female and Other (in early films such as Shivers, ${ }^{3}$ Rabid, and The Brood) to Psychological, Male and Self (in Videodrome, The Dead Zone, The Fly and Dead Ringers). And the tragic spectacle has been changed from one of mass destruction or predatory behaviour visited on non-central characters to one of private delusion, psychological disintegration and suicidal auto-destruction in the realm of the narratively central individual psyche. The forces are the same, but the analysis of responsibility and even the attribution of origin has altered. Also, we may characterize the horrors 
of Cronenberg's films in terms of a threatening otherness perceived from the standpoint of the films' self - a self which evolves from an apparently remote and impassive narrative persona in the films before Scanners to a stance of much closer identification with a male central character in the films following it.

For example, in Shivers the (socially motivated) work of a hubristic medical scientist produces a horrific organic parasite which transforms "normally" controlled, repressed apartment dwellers into ravenous sexual predators. There is nothing personal in this, and if the scientist is crazed, and if the final status of the victims has a meaningfully inverse relationship to their former one, the film presents none of its characters in any depth and is clearly trying to say something about the human condition in general rather than about the detailed condition of any individual - least of all the authorial sensibility's. The same pattern is reproduced globally in Rabid (1976) and The Brood (1979), though in each case the focus is more personal and the behaviour more individualized, and the degree of compassion for the characters' suffering correspondingly warmer. The "monster" in each of those films is female - and, in the male world of Cronenberg's narratives, other. (This is especially true given the narratives' constant connections between sexual desire, horrifying bodily transformation, and death.) The female monster, however, is often merely a conduit for a destructive force which has its origin elsewhere. The responsibility for the adverse condition remains dissipated among a number of sources: overweening scientists, human weakness, family pathology, chance or fate. Scanners (1980) represents an obvious turning point, moving at last to a central male protagonist and making some identification between the source of the monstrous and a male personal self - but it retains a mad scientist, banishes sexuality, and declines to identify the problem as a problem (telepathy can be used for good or evil; there is a "fusion" between the good and the monstrous brother scanners at the end).

Videodrome (1982) changes the emphasis. Violence and sexually-related visceral horror reappear, but this time they are embedded inside the personality of the male protagonist rather than appearing as "objectified" products of female-sourced 
monstrosity or of the innate imbalance of human nature. By following his most dangerous (sexual) impulses, Max Renn is catapulted into alienating nightmarish hallucination, crime, and finally suicide. Moreover the narrative locus is virtually indistinguishable from the protagonist's own viewpoint. The film is feverishly confused, and tries to assign responsibility for the horror simultaneously to malign external/social forces and to Max's corrupt (one might almost say sinful) nature. But however contradictory the text, there is certainly a far greater sense than ever before in Cronenberg's work that the prevailing sickness and depredation in the film is centred in the protagonist; that is, that

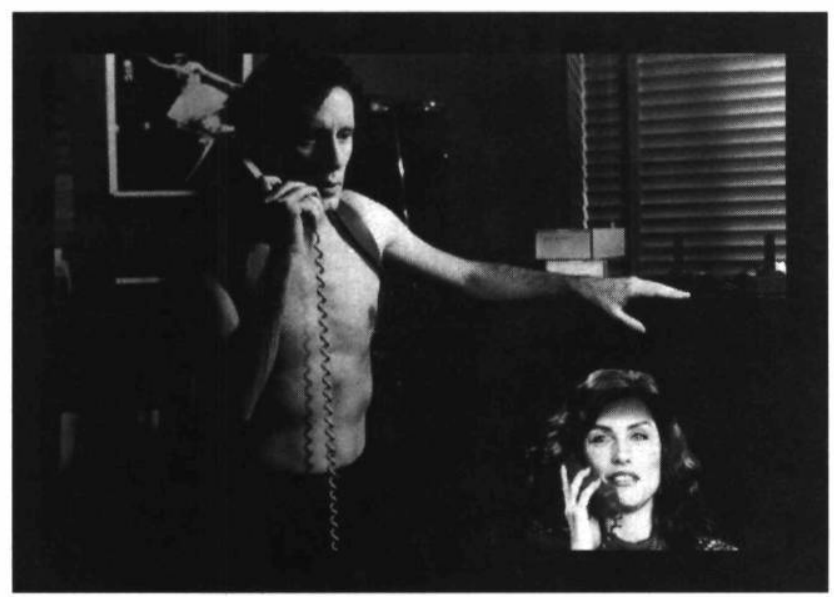

VIDEODROME

de David Cronenberg (1982)

Coll. Cinémathèque québécoise

unwholesomeness and horrific transformation (otherness) are not merely byproducts of the human condition applying to everyone equally (i.e. truly other), but rather somehow intimately connected to and created by the controlling sensibility (of the protagonist, and by extension of the narrational persona). By connecting a character's sick behaviour with his own peculiar psychological set, and by narratively privileging this central 
character, Videodrome, and Cronenberg's subsequent films, locate the source of contradiction in the first-person interior.

The Dead Zone (1984) continues the development by reviving the passive "nice" male hero of such earlier films as Rabid and The Brood, but - in the manner of Videodrome - centralizing him and investing him with a large measure of responsibility for his own plight. The wan, well-meaning, luckless victim-figure of Johnny Smith has in the end been represented as a romanticizing idealist crucially unable to believe in the possibility of his own ideals, a gentle defeatist who shapes his own prison of solitude, exclusion and passive suffering. The Dead Zone is still unable to accept complete responsibility for the emotional bleakness of Johnny's life as a freakish, solitary psychic Johnny has been hit by a truck just like Max Renn has been "infected" with predatory video signals - and there is still a willingness to devalorize the atrociousness of the protagonist's fate by reframing it in less painful terms: Max's suicide may perhaps be a transformation into a new form of life; Johnny's virtual suicide occurs in the context of an altruistic attempt to assassinate a future Hitler.

As in Videodrome the doorway to catastrophe continues to lie through the awakening of the (male) sexual impulse in general and relationships with women in particular. Wayne Drew quotes Cronenberg as saying:

To me the body is the centre of horror...the awareness of the body, the awareness of death, is the wellspring of horror... I am well aware of the relationship between sexuality and death. (16)

The earlier films identified women as other. The various sexually-predatory females in Shivers, Rose in Rabid, Nola in The Brood, were all represented as embodiments of self-destroying sexual otherness (where self is constructed as rational ego and the destruction is an irruption of the instinctive and the bodily triggered by desire). Principal males in these films mostly stood by and watched the carnage. By contrast, in all the films after Videodrome it may be women who trigger the horrors of otherness, but now otherness is depicted as something deep in the 
unconscious of the male protagonists waiting to be triggered ${ }^{4}$ There may be a problem with women in Cronenberg's films in fact there certainly is. But in Videodrome and the films which have followed, it is more and more clear — and the films have stated it as such - that it is the man's problem, the films problem, and not anything innate to women or really belonging to women at all. Again, the forces at work in the later films (in this case sexuality, its repression, its liberation) are the same as in the earlier ones, but the interpretation of them has changed significantly.

Simultaneously with this shift in responsibility for the destructiveness associated with intersexual relationships there has developed a parallel and complementary theme: that of solitude and exclusion. The inability of the Cronenberg protagonist to connect with others - and in particular to form a workable and lasting relationship with a woman - has come into focus more and more as a central emotional principle in his films. We may note his frequent interview references to his protagonists as "outsiders" or "people who don't belong." 5 Moreover the emotional alienation and depression accompanying isolation is associated progressively with physical dereliction and then with death. The theme is first articulated (fittingly) in Scanners, where the protagonist's special psychic gifts have been the very means of rendering him an outcast and a derelict. Max's terminally confused, murderous and suicidal final state in Videodrome is explicitly connected with a state of solitude indistinguishable from madness and with derelict physical surroundings. The Dead Zone similarly identifies Johnny's deterioration with the isolation enforced by his psychic condition and with a descent towards physical dereliction. Aloneness and sadness are characteristics of these films - as they are in different ways of The Fly and Dead Ringers as well. And increasingly the violent and visceral horrors of the films, varying in intensity and explicitness, are coupled directly with the syndrome of solitude and failure to connect, and both are seen as springing from the insoluble contradictions inside the male subject in the confrontation of rationality and sexuality.

Recently, Cronenberg has said that the underlying subject of 
all his films is the question of identity. ${ }^{6}$ From this perspective all the transformations and metamorphoses of Cronenberg's films may be seen as changes in identity, and their horrific qualities as deriving from a process of changing from self to other. The collapse of stable ego boundaries, loss of self, is the ultimate fear. But it is a specific configuration of loss which torments Cronenberg. Instinct and sexuality, indeed any form of strong emotion, becomes a threat to the rational control and sense of stability characterizing the ego-self. The nexus of sexuality, the body, and death (often through the metaphor of a cancer which gallops through the body changing healthy self-cells to monstrous other-cells) obliterates the self and replaces it with some horrifying exaggeration of "normal" desire or feeling. But, to complete the circle, the only way for the self to retain its identity is to protect itself from all emotional, and especially sexual, stimulus through isolation - and isolation is an intolerably empty and desolating condition. Cronenberg's later male protagonists are repeatedly driven from their isolation by the proddings of sexual instinct and the yearning for emotional connection. But when they forsake their hermetic cells they invariably encounter something so destructive that their last state is worse than their first; and that destructiveness arrives in the shape of some other self, which overpowers and displaces the familiar (solitary) egoself. Occasionally (in Scanners and Videodrome) Cronenberg has tried to imagine the other-self as not necessarily destructive, maybe even friendly - but he does not convince himself or the viewer. In The Dead Zone he tries to sustain the old ego-self as long as possible against the pull of instinct and yearning - but its life is pitiable. And in The Fly, the scenario is more oppressive than ever: the hero breaks out in ways more healthful and fulfilling than anything in Cronenberg, only to lose his self and suffer horrendous otherness in an ego-destruction of unparalleled awfulness.

We may turn our full attention at last to this film. In spite of the fact that Cronenberg shares the screenwriting credit with Charles Edward Pogue, there is no lack of a distinctive Cronenberg imprint in The Fly. ${ }^{7}$ Indeed one hardly knows where to begin in charting the elements familiar from other 
Cronenberg films. A bold and brilliant scientist (here the protagonist, Seth Brundle) invents a spectacular new device (an apparatus for teleportation in this case) which can revolutionize human life. It backfires, and destroys its intended beneficiary (in this case himself). The device is linked with the liberation of anti-rational, interior, visceral forces (here "the flesh") which appear to alleviate a condition of over-rationality, self-control and solitude (the shy and solitary Brundle embarks on a romantic relationship with a journalist, Veronica Quaife, and it is she who inspires him to the crucial insight which allows his machine to work on living forms). But the liberation goes too far, and produces a monster (drunk and jealous, Brundle overlooks a fly in the teleportation process and is genetically fused with it). The monster ("Brundlefly") represents the grotesque embodiment of long-repressed desires and fears (Brundle becomes first overtly obsessed with sex and power, then, in a galloping acceleration of the "fly" condition, is devoured and transformed by it). The condition takes the form of a horrific physical metamorphosis, one which is associated with the most extreme otherness, loss of identity and finally with death (Brundle slowly and in stages turns into a fly-creature; the change is explicitly described as a cancerous disease). The ending is one of unrelieved hopelessness and loss. The moral and the physical coincide visually as much as thematically, as an extended visual analysis might expound in detail. The mise-en-scène maintains the darker hues and the softer compositional and editing contours of Videodrome and Dead Zone rather than the cool, ironic primary-colour schematization of the earlier films; but there is still the detached wide-angle viewpoint punctuated with "hot spots" in decor and costume, and exploding periodically into the most explicit, regurgitative displays of violent visceral horror.

The protagonist, Seth Brundle, is a new amalgam of accustomed Cronenberg elements. Like Johnny Smith in The Dead Zone he is gentle, diffident and modest; he has charm, he is almost painfully likeable, the viewer feels protective of him. At the same time he is highly accomplished in his own way. He has reaped the reward of his solitude, his displacement of emotional energies into intellectual pursuits, his project of keeping his life 
under control through a stance of detachment which insulates him from turmoil and potential hurt. Simultaneously he actually occupies the role of powerful scientist - a role that hitherto in Cronenberg's work has always been removed into a more distant, more marginal, and usually older and more patriarchal figure. Typically this figure is responsible for loosing the plague on the world, though often with the best intentions. Seth Brundle invents teleportation, and he is the victim of his own invention. One might say that Cronenberg has finally united those two disparate male archetypes of his early films - the passive, "nice," ineffectual jeune premier and the active, menacing, potent fatherscientist. Thus he has made the central male subject into both perpetrator and victim; and one must regard this development, I believe, as a movement in the direction of integration and acknowledgment that chaos and the terror of otherness are selfderived. The ills of the Cronenberg world, in other words, can no longer be ascribed to a distant source and merely suffered by the central character; they are now wholly generated by the same self which manifests their terrible symptoms. ${ }^{8}$

At the same time the process whereby this emotional exile is drawn into a real, reciprocal relationship with a woman and is freed from his prison of isolation is a more substantial and convincing one than in any other Cronenberg film. For awhile - if only for awhile - the male subject breaks out of his monastic state of personal repression and enters into an emotional dialogue with the heroine that is simultaneously the most unexpected and unprecedented thing (from the standpoint of the Cronenberg world) and the most familiar and even commonplace (in the context of "normal" commercial-cinema narrative). Seth asks Ronnie with surprise "Is this a romance we're having?" (the viewer answers loudly in the affirmative); Ronnie describes them as "like an old married couple;" the film itself was widely described as "a love story." It is necessary to reiterate how extraordinary a development this is in Cronenberg's films, which both before and since have been rooted in the feeling that such relationships cannot exist for the films' protagonists. This is particularly striking after The Dead Zone, where the essence of Johnny Smith's exquisite torment is that a "normal" domestic life 
of love, sex and family is dangled enticingly in front of his nose and then forever denied to him. (The deluded and corrupted Max Renn in Videodrome can only distantly glimpse such prospects.) The state of exclusion from this best-publicized form of close human contact seems like a condition of life for the Cronenberg-persona. It is not too surprising to find as a consequence that the films routinely idealize and romanticize this yearned-for but forbidden country. Only in The Fly is there a fully-realized romance, wholly participated in by the protagonist.

But of course it is very temporary: it remains a law in Cronenberg's world that wholeness and contact are impossible, that balance, un-repression, and reconciliation of contradictions cannot occur. The sickness at the heart of this world remains essentially intact, even if some of its mechanisms are now more clearly understood. Liberation from solitude brings only momentary equilibrium and wholeness; then the deeper and unconquerable forces of separation, denial and traumatic alienation reassert themselves in a form infinitely more powerful for having been disturbed in their numb dormancy. So in the end The Fly is an almost intolerably painful film, as warmth and harmony are evoked and then inexorably transformed into the most appalling horror.

The product of Brundle's hermetic, sublimated scientific life is a teleportation machine. He says he developed it to free mankind from the unpleasant physical effects of movement: he himself suffers badly from motion sickness. Brundle's computer analyses the thing to be teleported, memorizes its molecular structure, dissolves the object and reconstitutes its molecules exactly in a different place. The object having been teleported is not itself, then, but rather a "perfect" artificial simulacrum. In effect, Brundle has invented a fantastically elaborate cybernetic substitute for a simple physical phenomenon. The notion of an artificial reconstitution also suggests the substitution of reason and calculation for the physical and the instinctive. That this is another of Cronenberg's mind-body metaphors becomes even clearer when it is revealed that although the machine can teleport Ronnie's sheer black stocking (and here is evoked an idea of 
the body and of sexuality), it cannot reconstitute living things successfully. An ape is spectacularly and disgustingly turned inside out by it. "The flesh", to use Brundle's (and emphatically Cronenberg's) term, has something unknowable, un-rational, about it. And because the computer knows nothing except what Brundle tells it and is hence nothing but an extension of him, and because he knows nothing about "the flesh," the device suffers his limitation. Only after Brundle begins an affair with Ronnie does he learn enough to reprogram the computer. His inspiration comes directly from a tender post-coital scene? in which, pinching him playfully, Ronnie says:

I'm gonna eat you up! You know, this is why old ladies pinch babies' cheeks. It's the flesh — it makes you crazy.

Brundle proceeds to teach the computer to "be made crazy by the flesh". It is his own craziness, of course, which is communicated to the machine; and the catastrophes to come, although they have their realist diegetic alibis, are the product of that craziness. But at first the teleportation of living flesh (another baboon) is a success.

Brundle's condition at this point is one of bliss. He has found a companion, he has found a sexual partner, and he has made an astounding scientific breakthrough. This is the one moment of human wholeness and fulfilment in all of Cronenberg's work. ${ }^{10}$ It is very brief. Immediately, within minutes even, unclouded happiness gives way to sexual jealousy as Ronnie runs off to confront her old boyfriend Stathis Borans who (himself motivated by sexual jealousy) is making a nuisance of himself. Brundle begins to lose his self-possession, and thus starts down the road to loss of self. Drunk literally with the wine of celebration, and subject now to the unfamiliar turmoil of sexual possessiveness and threatening ego-wounds, Brundle decides quite arbitrarily to go through the teleportation process himself. Overlooked by him (though not by the un-neurotic teleported ape with whom he has been conversing), and insinuating itself into the telepod with him, is a fly. The process fuses the two organisms, although the fact is not apparent to anyone for some time.

The fly is of course the representation of that monstrous 
otherness which Brundle has admitted to his soul in opening himself to human and sexual contact, to "the flesh". Once more it is asserted that there is no real alternative to solitude and rational sublimation, as unsatisfactory as the latter condition may be. Cronenberg's preceding film, The Dead Zone, had immersed itself in a detailed exposition of the tragic consequences of isolation. In The Fly, Brundle escapes from that state, but at such an appalling eventual cost that the escape is seen as the very opposite of the solution to a problem. Human closeness, romantic attachment, sexual intimacy, are all seen as leading inexorably to visceral horror - a combination of sexual alienation, fear of the sexual other (which is both woman and the feelings woman arouses in the male self), sexual guilt resulting from these feelings, fear of loss of control and loss of self, terror of the spirit's subjugation to and foundation in the body and its inevitable dissolution in bodily decay, disease and death.

This is the state of "flyness". Its status as the emblem of otherness is admirably signalled by its insectness: no animate life form inspires a more revulsive and alienating set of instinctive responses in humans. The process of transformation is complex and extended, and may be divided into four stages, of which the last two are brief and occur in quick succession in the final scene. The first is a transitional period before Brundle realises what is happening to him; the second coincides with the recognition of his state and the gradual growth of "fly" characteristics; the third arrives when Seth's self has finally been obliterated by "flyness"; and the last is the hideous result of an accidental mating of "Brundlefly" with one of the telepods.

In many ways the most intriguing of all is the first stage, in which the changes are relatively subtle, and are interpreted by Brundle not as disease or otherness but as a positive growth and a form of self-realization. The first symptoms (apart from one ambiguous shot of hairs emerging from his microchip-wound) are indeed simply those of subjective exhilaration. Brundle sits in a café with Ronnie, heaping spoon after spoon of sugar into his cappuccino and babbling breathlessly about self-realization. For a moment we see him poised vertiginously between personal fulfilment and the slide to destruction. Brundle is soon 
comparing this emotional rush with the effects of a drug - and in fact the world of the drug-user is soon being evoked in many details. Cronenberg's use of drug addiction as a metaphor for the collapse of the controlling ego and the loosing of all kinds of destructive monsters of disorder may also be seen, much more fully articulated, in Dead Ringers. It seems reasonable to trace the connection back to William Burroughs' modernist novel of heroin addition and monstrous liberated unconscious Naked Lunch, which Cronenberg has recently adapted adapted to the screen, and which he has often cited ${ }^{11}$ as an important early influence. Indeed, a link between Naked Lunch and The Fly is also suggested by the novel's many references to "insect" qualities — as for example:

C [i.e. cocaine] pleasure could be felt by a thinking machine, the first stirrings of hideous insect life. (Burroughs, 24)

and

Faces of The City poured through silent as fish, stained with vile addictions and insect lusts. (52)

Such characterizations of the insect state as representing the most horrific of all departures from ego-humanity are fully in keeping with Cronenberg's use of the idea in his film.

Brundle also begins to feel very strong physically - the equivalent of the insect's enormous strength-to-size ratio. His highly developed physique is now emphasized by repeatedly showing him barechested; he gets hairier (he says he likes this and always felt "too boyish" before); he begins to perform amazing athletic and gymnastic feats; his sexual stamina is endless and his appetite insatiable; he gobbles down Oreo ice cream and sugar donuts and candy bars. His temper too becomes more selfcentred; satisfying his new appetites becomes a compelling imperative; he begins to move into übermenschlichkeit and egomania. He becomes obsessed with getting Ronnie to teleport too - he needs a superwoman. When she refuses and suggests there is something wrong with him he says drug-addict things like "You're a fucking DRAG, you know that?", and "You'll do anything to bring me down." Blotches begin to appear on his face. 
Now he goes out in search of a more suitable sexual partner (Ronnie is "too chickenshit"), and where he goes is into the urban jungle of streets in the wrong part of town and sleazy bars. Here he effortlessly assumes the argot of the lumpen denizens, armwrestles a beer-drinking sub-proletarian (and literally breaks his arm in two) and makes off with the man's chesty sequin-jacketed girlfriend as a prize of combat.

All of this represents a precipitous descent for Brundle in terms of "good taste", and in terms of social class. Forsaking the fastidious and well-behaved world of the repressed intellectual, Brundle plunges into a nightmare of crude appetite and tasteless indulgence. The initial phase of otherness is a loss of standards, the disappearance of politeness and "decency." Brundle, a nice, sweet, considerate man, turns into a degenerate hippie drugaddict macho redneck with delusions of grandeur. This is what happens when you "let go". Does it reveal a somewhat puritanical attitude for which decorum and self-possession are inseparable from the concept of the ego-self, and for which physical sloppiness, junk-food bingeing, "a lack of self-respect", "selfindulgence", are early signals of the emergence of a corrupt and ill-mannered $\mathrm{Mr}$ Hyde whose lurking existence must always be circumscribed through vigilance and self-control? Certainly Brundle's transformation from a polite, well-controlled person who keeps his distance to a sex-crazed punk who picks up women in cheap bars to (eventually) a thing that vomits slime onto its Twinkies is not so far away from the obsessive Calvinist dichotomies of Paul Schrader's work.

Brundle recovers his modesty in the second stage of his flyness. It returns when he is forced to identify his transformation as a movement in the direction of decay and death. In effect flyness equals both id and loss of self. Hitherto Brundle has mistaken the powerful flexing of the unconscious's muscles as a growth of ego. But really they are the stirrings of the fly-self, which is not self but other, or rather other-self. Earlier I said that Brundle is depicted as admitting monstrous otherness into himself. But in fact, The Fly makes it clearer than any previous Cronenberg film that the otherness is actually inherent in the self, only latent and buried; and that the inauguration of sexual expression and 
emotional intimacy merely uncovers and frees what was always there. When Brundle's fingernail pops off and a milky white liquid spurts from the uncovered end (in a surreally shocking image of both sexuality and sexual disease), realization comes to him with horrible suddenness. Trying to discover what went wrong, he asks the computer to re-run the teleportation sequence; this is visualized on the monitor as a series of pictures going from macro (an outline of Brundle's body) to micro (cellular- and molecular-level pictures of the reconstituted creature). As Brundlefly is formed, a ghastly transformation occurs at the most basic level of being: the cells and forms take on terrible insect-like characteristics. Seth looks at the computer's graphic presentation of his own essential innermost self and sees something horrific and alien. He himself is other at the most primary integral level. This is a frisson-generating moment, one which situates the film in a tradition of alien-self horror and science fiction, ${ }^{12}$ and which emphasizes the point that what is truly horrific here is not outside but inside.

Now comes the whole process of external physical transformation. Although this process is supposed to be a metamorphosis, it is rendered less as a change into a new form than as a corruption and decay of the human self. Its very first symptoms, which co-exist with the previous megalomaniac phase, are the fibrebristles on the back and a certain splotchiness of complexion. This process of increasing discoloration and lumpiness is instantly associated with the idea of disease. As the process escalates there is a greater and greater emphasis on decay, corruption, and decomposition, producing extreme physical revulsion both in the viewer and in Brundle himself. Fingernails, teeth, ears, and other unspecified body parts actually fall off or come out (Brundle stores them in his bathroom medicine chest); the process of bodily dissolution is as horrifying and disgusting as Cronenberg can make it.

The disease mentioned specifically in the film is cancer normally thought of as an "invisible" internal disease whose outward manifestations are indirect (a drastic thinning and self-consumption, for example). And in fact the idea of cancer as a disease which progresses by the multiplication of abnormal cells 
and the transformation of normal cells into abnormal ones, has an appropriateness not only to the idea of fly-cells replacing and taking over Brundle-cells, but in the notion of secret otherness released from dormancy and inexorably devouring and replacing the self. But in The Fly it is as though the internal cancerous process were made manifest and visible. The disease bears more resemblance in its external effects to leprosy. Indeed there is a stage at which Brundle is virtually crying "unclean!" For example, when Ronnie sees him for the first time in a state of advanced "decay," he is reluctant to go near her out of a consciousness of his own ugliness. When she tries to give him a hug, he shies away, saying "you're so pretty" (and by implication "you shouldn't be touching anything as disgusting as me"). This reflects that almost lonely-adolescent sense of lack of confidence in relationships with women and resigned sense of exclusion which rhymes so easily with Brundle's pre-Ronnie, pre-teleportation period (in this respect he is very like the protagonist of The Dead Zone). Again, Seth's transformation into a monster of ugliness can be seen rather as a reversion to a prior, more properly innate status: the fly is what Seth always was, secretly, really ("I am a fly who dreamt he was a man"). But although the "leprous" qualities are marked, the philosophical attractions, as it were, of cancer are too compelling to be displaced. Brundle's forceful assertion that "I won't be just another tumorous bore, talking endlessly about his hair falling out and his lost lymph nodes" definitely identifies Brundle's state with that of a clinical cancer patient.

Clearly cancer means something to Cronenberg - it is mentioned by name or imbedded in the thematic landscape throughout his work, and constitutes for him what Wayne Drew has aptly called "that perpetual nightmare in Cronenberg's films." (17) In The Fly it is synonymous with the horrific inevitable end of the narrative's line: with loss of self and secret resident otherness, with the body as a site of the uncontrollable and the dangerous, with flyness, with explicit physically awful death. The process of Seth's transformation from a sweet, shy, brilliant, valuable human being into a mass of pus and decay who becomes psychologically twisted into a predatory alien thing is one which 
Cronenberg regards not simply with horror and sadness but as the realization of his deepest and most persistent fears.

And this must be the ultimate refutation of Cronenberg's own often-stated attitude of dispassionate curiosity about the visceral, the "abnormal" and the un-human. Certainly he has sought to deal with this range of connected threatening ideas with "scientific" detachment. He testifies to a boyhood fascination with insects and reptiles, and with internal anatomy, and recalls finding those things, which others reacted to in horror, "beautiful." 13 He talks with measured detachment about the contradictions of human nature, and how the overthrow of Cartesian rationality is merely inevitable - and in fact the objective correlative of this detached tone is to be found in the cool mise-en-scène of, especially, the early films. He speaks of identifying with the parasites in Shivers. ${ }^{14}$ This viewpoint has its correlative in The Fly in Seth's attitude of cynical detachment to the transformation he is undergoing. As he puts his newly-fallen-out teeth in the medicine chest, he bids them an ironic farewell and characterizes them as now "only of archival interest." He describes the disease to Ronnie in these terms:

I know what the disease wants. ${ }^{15}$ It wants to change me into something else. That's not so terribly bad, is it? Most people would give anything to be changed into something else.

Then he invites her to videorecord his demonstration of flyness, a stomach-turning display of external (vomited-performed) predigestion which he accompanies with an explanatory narrative which nastily parodies that of a children's science-show host. Brundle's flyness is emphatically not a subject for interested detachment. Events become more and more horrifying until the moment of transition to the final stage, where, after Ronnie rips his jaw off, his skin falls away, his facial features fall apart, and the insect appears. This insect is totally and unambiguously monstrous and other in the most terrifying sense: of our Seth, of his own Seth, there is no trace remaining. Flyness may well be "interesting" from one (detached) standpoint: look at all the things he can do, he's tremendously strong, he eats enormous quantities of sweets, he walks on the ceiling; later: look what's 
happening to his skin and hair, look at how he regurgitates enzymes onto his food. But at the deepest, most final and meaningful level it is awful, nauseating, unbearably sad. Brundle's confusion and embarrassment as Ronnie witnesses the effects of his transformation; the lostness and fear in his voice when his ear falls off ("oh... my... ear"); his wish for his child to be preserved ("all that's left of the real me") and his piteous acceptance of Ronnie's decision to abort ("too bad, too bad") — all of these things represent the pathos and the awfulness of the deterioration and death of a human being and are as far as possible from the stance of curious detachment.

This third phase of "flyness," marking the disappearance of Brundle and the sole survival of Brundle $f l y$, is signalled by a striking speech to Ronnie in which the last glimmer of Seth announces his own oblivion:

\begin{abstract}
Have you ever heard of insect politics? Neither have I. Insects don't have politics. They're very brutal — no compassion no compromise. We can't trust the insect. I'd like to become the first insect politician - you see I'd like to, but, ah, ah I'm afraid... I'm saying I'm an insect - who dreamt he was a man, and loved it - but now the dream is over, and the insect is awake.
\end{abstract}

Otherness is brutal, with no human sensibility. The ugliness of the final scenes is implied here, an ugliness of which the viewer is spared nothing. These scenes contain the most explicit and horrifying "physical" special effects, as always in Cronenberg the direct expression of the anguish and despair underlying the whole action, and culminating in the pathetic and monstrous spectacle of Brundlefly mated with the telepod - itself a kind of quod erat demonstrandum of the impossibility of mating rationality with the flesh. At the end of the film there is no light, no consolation, nothing but the obliteration of Seth Brundle amidst circumstances of the utmost horror and the traumatic suffering of his lover.

In its transportation of the recurring horrors of Cronenberg's world to a site inside the narrative persona (for the narrative locus in the film is closely identified with the protagonist), The Fly demonstrates what one may describe, in therapeutic terms, as 
a growth in self-understanding. From this perspective it might be said that the ongoing drama in Cronenberg's films is the illustration of a psychological neurosis of the narrative persona. The films have presented an obsessively-repeated fear of desire, sexuality, intimacy, and emotional release; the punishments for invoking this realm or responding to its lure include gross delusion, cancerous bodily deformation, monstrous predatory violence and death. Correspondingly the films have manifested, if only by implication, an attachment to repression and control as necessary though self-desolating instruments of psychological survival. A state of anguish and despair is the resulting logical condition of the films' sensibilities. In earlier films this extreme imbalance was seen as an aspect of "the human condition" with both its causes and its symptoms grounded in objective external circumstances. But as the films have turned more intensely to an examination of their own psychology (by the structural expedient of personifying that psychology more concentratedly in a central male character), they have increasingly discovered the causes of psychological disfunction in a configuration of conflicting imperatives within the persona itself. The Fly's narrative content is essentially a metaphor for this understanding, just as the film's Affekt is an expression of the despair felt at such a prospect. For, contrary to at least some therapeutic models, an understanding of the self-generating and self-perpetuating mechanisms of the neurosis has done nothing to mitigate the neurotic symptoms. If anything the effect has been quite the reverse: as Cronenberg's films have more and more renounced "objective" outside agency (e.g. women, lunatic rationalists, social predators, human nature in general, bad luck) as a cause for the horror, they have become sadder, more hopeless, more tormented. The Fly and Dead Ringers are not only high-water-marks of despair in the always pessimistic world of Cronenberg's films, but also virtually unparalleled in this respect in current commercial cinema. So despite the growth in self-inquisition and the unflinching self-incrimination in these films, they cannot exactly be described as "progressive" and they are definitely not therapeutic. 


\section{NOTES}

1 See Piers Handling (ed.), The Shape of Rage (Toronto: Academy of Canadian Cinema, 1983) for a multiplicity of viewpoints of Cronenberg's earlier work, a number of them emphasizing the prevalence of a "mind-body" thematic in the films. Also David Chute, "He Came From Within", Film Comment, Vol. 16 n² 2 (March-April 1980 ) and Wayne Drew, "A Gothic Revival: Obsession and Fascination in the Films of David Cronenberg," in Wayne Drew (ed.), David Cronenberg (London: British Film Institute, 1984) 16-22.

2 For related commentaries on the films preceding The Fly see William Beard, "The Visceral Mind" in The Shape of Rage, and "An Anatomy of Melancholy: Cronenberg's Dead Zone" in The Journal of Canadian Studies, Winter 1992-93.

3 I use this, the Canadian title, throughout; in the United States the film was released as They Came From Within and in the United Kingdom as The Parasite Murders.

4 It is interesting and instructive to watch the films lay out this pattern across the widest variety of intersexual circumstances. Where Max Renn's physical relationships are sexually highly charged and his fantasies sadistic, Johnny Smith's chivalrous romantic attachment is averted, postponed, and denied, and his emotional stance is that of a masochist. In The Fly the relationship is a full-blooded romance brought to complete (albeit temporary) fulfilment. Yet another version of the pattern may be found in Dead Ringers - one which is able to encompass virtually the whole spectrum due to the stereoscopic possibilities inherent in splitting the protagonist into psychologically diverse twins.

5 See especially Jill McGreal, "Interview with David Cronenberg," in Drew, pp. 3-15.

6 Interview with George Hickenlooper in Cinéaste, Vol. 17 n 2 (1989), pp. 4-7.

7 Nor is there in The Dead Zone where sole screenwriting credit goes to Jeffrey Boam, and there is a Stephen King bestseller to be mimed.

8 This development takes its place in a linear progression: in Scanners, the male subject first assumes centre stage, but the engine of change, otherness, difference, is still the separate character of the patriarchal scientist (in this case literally the father, Dr Paul Ruth); in Videodrome, responsibility is awkwardly shared between Max himself and the predatory and/or patriarchal figures of Barry Convex and Brian O'Blivion; in The Dead Zone it is likewise shared, but now the external force is de-personified into chance, or fate (the protagonist is hit by a truck), while the patriarchal scientist-figure (Johnny's doctor, Weizack) is deprived of any decisive power and made entirely benevolent. Dead Ringers continues The Fly's strategy of locating the origin of disastrous catalysis - in so far as it exists at all in this film - in the self of the protagonists: the twin gynaecologist Mantle brothers.

9 In this same scene there is a small but pungent piece of foreshadowing, as Brundle gets a tiny spiked microchip imbedded in his back. This diminutive scientific-ambition wound, inflicted in a coital arena, is later the first site of Brundle's flytransformation, as bristling black hairs emerge from the spot in place of the microchip pins. Like the organic images connected with the telepods (their intestinal cables, their final mating with Brundlefly), this is another of the film's machine/organism (mind/body) tropes.

10 With the possible exception of the ending of Scanners - where however the wholeness is idealized and certainly desexualized.

11 See, for example, a number of references to Burroughs in the interview in The Shape of Rage, especially pp. 193-194. 
12 The line extends in science-fiction films at least from the 1956 Invasion of the Body Snatchers to the recent Total Recall (a project which Cronenberg was to do at one stage) and has obvious affinities with the related Jekyll-and-Hyde tradition.

13 Dead Ringers has more to say on this subject. The fascination of the Mantle twins with gynaecology, and with the gynaecologically "abnormal", dates back to childhood. And Beverly's mad project to design and produce gynaecological instruments for "deformed women" is a quasi-artistic endeavour suggested by a sculptural exhibition and actually made by a sculptor.

14 Interview with Beard and Handling, in The Shape of Rage, p. 179.

15 This is an extension of his earlier line: "I seem to have been stricken by a disease with a purpose". This moment is itself an echo, not least in tone of voice, of a comment in The Brood where one of Dr. Raglan's patients (Jan Hartog), also visibly deformed, speaks of his efforts to combat lymphatic cancer induced by Raglan's "psychoplasmics" therapy: "Dr Raglan encouraged my body to revolt; now I've got a small revolution on my hands and I'm not putting it down very well."

\section{WORKS CITED}

Burroughs, William. Naked Lunch. New York: Grove Press, 1959.

Drew, Wayne, "A Gothic Revival: Obsession and Fascination in the Films of David Cronenberg," in Wayne Drew (ed.). David Cronenberg. London: British Film Institute, 1984. 